\title{
Mass spectrometric identification, characterization and validation of the haptoglobin $\beta$-chain protein as a lung cancer serum biomarker
}

\author{
ASIMA AYYUB $^{1}$, MAHJABEEN SALEEM ${ }^{1}$, SYED GHULAM MUSHARRAF $^{2}$, \\ MAMOONA NAZ ${ }^{1}$, ASMA TARIQ ${ }^{3}$ and NAGHMA HASHMI ${ }^{2}$ \\ ${ }^{1}$ Institute of Biochemistry and Biotechnology, University of the Punjab, Lahore 54590; \\ ${ }^{2}$ Hussain Ebrahim Jamal Research Institute, University of Karachi, Karachi 75270; \\ ${ }^{3}$ School of Biological Sciences, University of the Punjab, Lahore 54590, Pakistan
}

Received January 30, 2014; Accepted November 7, 2014

DOI: $10.3892 / \mathrm{mmr} .2015 .3822$

\begin{abstract}
Lung cancer is the major contributor to overall cancer-related mortality. Biomarkers are important in early detection and prognosis, in addition to developing treatment regimes, which may improve the patient survival rates. Biomarkers may also assist in investigating the in depth metabolic pathways and in establishing a set of therapeutic agents leading to early detection of the disease. The present study was designed to identify and confirm a lung cancer protein biomarker and to correlate the differential expression of the protein to a particular histological disease type. A total of 100 lung cancer patients and 50 healthy controls were included in the present study and were categorized into the two main histological types of lung cancer; non-small cell lung cancer (NSCLC; $n=88$ ) and small cell lung cancer (SCLC; n=12). NSCLC was further subclassified into three histological types; adenocarcinoma $(n=34)$, squamous cell carcinoma $(n=48)$ and large cell carcinoma $(n=6)$. The patient and control serum samples underwent sodium dodecyl sulphate polyacrylamide gel electrophoresis characterization followed by two-dimensional gel electrophoresis. Following mass spectrometry, human haptoglobin was identified with a mass of $\sim 42-46 \mathrm{kDa}$ and an isoelectric point (pI) of $~ 5.5-6.2$. The experimental mass of the protein was found to be $45.8 \mathrm{kDa}$ with a $\mathrm{pI}$ of 6.13 . The matrix-assisted laser desorption/ionization time-of-flight/time-of-flight data exhibited spectral peaks of $1146.134,1724.191,1345.339$ and $2210.319 \mathrm{~m} / \mathrm{z}$ and Mascot search analysis identified these peaks as haptoglobin (accession no. P00738; Mascot score 87; sequence coverage 23\%).
\end{abstract}

Correspondence to: Dr Mahjabeen Saleem, Institute of Biochemistry and Biotechnology, University of the Punjab, Lahore 54590, Pakistan E-mail: mahjabeensaleem1@hotmail.com

Key words: haptoglobin $\beta$, lung cancer, two-dimensional gel electrophoresis,biomarker,matrix-assistedlaserdesorption/ionization time-of-flight/time-of-flight
This protein was significantly overexpressed in squamous cell carcinoma and adenocarcinoma, as compared with the control. The present study described differentially expressed human haptoglobin as a lung cancer serum protein biomarker, which may serve as a diagnostic and therapeutic target and set a standard criteria for the evaluation of histological types of lung cancer compared with other disease types.

\section{Introduction}

Lung cancer is the most common cause of cancer-related mortality in males and females in the USA with a frequency of 160,000 new cases per annum. The prognosis is poor, as is evident from low survival rates; the five- and 10-year total survival rates for patients receiving therapy were only 14 and $8 \%$, respectively (1). Lung cancer is classified into four main histological types, which are categorized into two large groups: Non-small cell lung cancer (NSCLC) and small cell lung cancer (SCLC). NSCLC, contributing to $80 \%$ of lung carcinoma, is further subdivided into three sub-types based upon histopathological screening and comprises squamous cell carcinoma, large cell carcinoma and adenocarcinoma of the lung, which contribute to $20-25 \%, 15-20 \%$ and $30-40 \%$ of lung cancer cases, respectively (2).

A biomarker is defined as any type of specific parameter used for estimation of biological homeostasis, which has the ability to discriminate 'abnormal' from 'normal' (3). It may also be referred to as a molecule predicting any deviation from normal physiology (4). Cancer biomarkers provide valuable direction in the field of cancer biology. They not only assist in early cancer screening, but they offer valuable information for the investigation of cancer stage and treatment sensitivity (5). The clinical information provided by cancer biomarkers is important in the selection of appropriate treatment, which leads to personalized cancer therapy (6). Carcinoembryonic antigen, cytokeratin fragment-19, neuron-specific enolase and cancer antigen-125 are a number of candidate lung cancer biomarkers (7).

Proteins are excreted as a result of tumor growth and appear in serum fractions (8). Therefore, serum can be used as 
an indicator of any undergoing lesion in the body and it is used in proteomic research as a screening parameter in biomarker investigation. Protein profiling methodologies, including two-dimensional gel electrophoresis (2DE) and matrix-assisted laser desorption/ionization time-of-flight/time-of-flight (MALDI/TOF/TOF) offer versatile and systematic research tools in disease screening and handling and enable the analysis of complex protein mixtures (4). Proteomic methodologies are important in the recognition of disease biomarkers and are emerging as a key subject in current health issues. Therefore, oncoproteomic investigations provide a direct method of cancer screening at the single cancer patient level.

Haptoglobin is a positive acute-phase protein, which is produced mainly in liver cells against the acute host inflammatory response to stimuli (9) and is reported to be a predictor of lung cancer (10). It attaches to hemoglobin and acts as a biomarker of hemolysis (11). The haptoglobin protein exists naturally as a tetramer comprised of two $\alpha$-and two $\beta$-subunits, which are linked by disulfide bonds (12). Unlike the $\beta$-subunit, which has no isoforms, two isoforms of the $\alpha$-chain exist: $\alpha-1$ and $\alpha-2$ (13). A high degree of glycosylation is one of the significant features of $\beta$-haptoglobin. The $\beta$-subunit contains 243 amino acids and has a molecular weight of $>40 \mathrm{kDa}(13)$. Upregulation of the haptoglobin $\beta$-chain has been noted in adenocarcinoma of the lung and in several different types of cancer compared with that in normal individuals (7). This observation supports the hypothesis that overexpression of the haptoglobin $\beta$-chain may act as a useful biomarker for lung cancer (7).

In the present study, sodium dodecyl sulphate polyacrylamide gel electrophoresis (SDS-PAGE), 2DE coupled with in-gel digestion, MALDI/TOF/TOF and western blotting were used to identify and confirm haptoglobin as a lung cancer biomarker protein. The effective implementation of these proteomic approaches may assist in identifying differentially expressed lung cancer serum proteins compared with controls, as well as to elaborate the important role of disease-specific biomarker proteins.

\section{Materials and methods}

Sampling. Blood samples were collected from lung cancer patients from the Allah Wali Oncology ward of Gulab Devi Chest Hospital (Lahore, Pakistan) with permission of the hospital administration and legal authenticated reviews from the ethical committee of the University of the Punjab (Lahore, Pakistan). Written informed consent was obtained from the patients. The lung cancer patient group consisted of 100 participants, including males aged $44-72$ years $(n=85)$ and females aged $36-55$ years $(n=15)$. The control group consisted of 50 healthy individuals, including males aged 23-73 years and females aged 29-57 years. Only patients diagnosed with lung cancer were included, excluding of all non-cancerous chest diseases and the samples were categorized into two main histopathological types: NSCLC, which was further sub-divided into adenocarcinoma, squamous cell carcinoma and large cell carcinoma and SCLC. Differentiation of carcinoma type was based upon microscopic observations and immunohistochemical staining. These types were based on biopsy reports of the patients examined by a consultant
Table I. Clinical biological data of patients with lung cancer.

Histopathology of

lung cancer

$\mathrm{n}$

Non-small cell lung

carcinoma/adenocarcinoma

Squamous cell

carcinoma

Large cell lung

carcinoma

Small cell lung

carcinoma

Work-related probability

of malignancy (male/female)

Smoking exposure (years; male/female)

Surgical resection cases (male/female)

$8-22 / 1-3$

histopathologist. The parameters recorded by a survey in the present study, included age, gender, occupation, smoking habits, socioeconomic status, area of geographical location, family size, any past disease, site of tumor or lymph node, side of affected lung and signs/symptoms. The clinical biological data of the patients is presented in Table I.

Serum preparation and protein quantification. A total of $10 \mathrm{ml}$ venous blood was aspirated by sterile disposable syringes and immediately transferred to a clot activator tube (silicon coated) to boost the blood clotting process. Following transfer of the blood into the tubes, the blood collection tubes were stored on ice in order to ensure the integrity of the sample during transportation to the laboratory. The serum was collected after $25 \mathrm{~min}$ incubation of the blood sample at room temperature $\left(30^{\circ} \mathrm{C}\right)$ and the transparent top liquid fraction was carefully removed followed by centrifugation at 4,000 rpm for $10 \mathrm{~min}$ and was stored at $-80^{\circ} \mathrm{C}$ for further proteomic profiling and quantitative evaluation. All the samples were processed in a similar manner.

The total protein contents in the control and patient serum samples were estimated following Bradford's dye binding method (14). A standard curve was plotted between the appropriate concentration standards of bovine serum albumin (Sigma-Aldrich, St. Louis, MO, USA) between $20 \mu \mathrm{g} / \mathrm{ml}$ and $160 \mu \mathrm{g} / \mathrm{ml}$ and their respective absorbance values were measured at $595 \mathrm{~nm}$.

SDS-PAGE of the serum samples. SDS-PAGE is a commonly used technique for the qualitative study of complex protein mixtures. This type of resolution of proteins and peptides enables the estimation of a certain protein/peptide in an analytical specimen and results in assessment of the antigentic capacity of the proteins and peptides by coupling SDS-PAGE with immuno-electroblotting (15). The SDS-PAGE was performed according to the method described by Laemmli (16) and the gels were placed in fixative solution containing $30 \%$ ethanol, $10 \%$ acetic acid and $60 \%$ deionized water for $4 \mathrm{~h}$, washed with deionized water and stained overnight 
Table II. Outline of isoelectric focusing conditions for immobilized $\mathrm{pH}$ gradient strips.

\begin{tabular}{lccr}
\hline Steps & Voltage $(\mathrm{V})$ & Time $(\mathrm{h})$ & Duration $($ Vh) \\
\hline Step 1 & 150 & 01 & 150 \\
Step 2 & 300 & 01 & 300 \\
Step 3 & 600 & 01 & 600 \\
Step 4 & 1000 & 12 & 12000 \\
Step 5 & 2000 & 05 & 10000 \\
Safety step 6 & 3000 & 02 & 6000 \\
Step 7 & 4000 & 08 & 32000 \\
\hline
\end{tabular}

with $50 \mathrm{ml}$ colloidal Coomassie stain G-250 (Sigma-Aldrich), which was prepared by mixing $40 \mathrm{ml}$ stain and $10 \mathrm{ml}$ freshly added methanol. Destaining was performed by frequent changes of fresh deionized water until the entire background of the gel was cleared. This was scanned using a gel documentation system (GeneSnap; Syngene, Cambridge, UK). All the samples were resolved in the same manner for characterization of the differentially expressed protein profile.

\section{$2 D E$.}

The 2DE technique provides an improved resolution and fine separation of proteins with accurate molecular weights and information regarding isoelectric points. The technique involved the following sequential steps:

Rehydration. Immobilized $\mathrm{pH}$ gradient (IPG) strips of $18 \mathrm{~cm}$ in length (Serva, Heidelberg, Germany), were added to $350 \mu 1$ rehydration buffer, which was prepared by dissolving $4.8 \mathrm{~g}$ urea and $0.1 \mathrm{~g}$ 3-(3-cholamidopropyl) dimethylammonio propanesulfonate in $10 \mathrm{ml}$ deionized water followed by the addition of $0.02 \mathrm{~g}$ dithiothreitol (DTT; cat no. R0861; Fermentas, Pittsburgh, PA, USA), $125 \mu$ l servalyte (pH 3-10; cat no. 42940; Serva) and $0.0002 \%$ bromophenol blue. Silicon oil (1-2 ml; Fluka, Buchs, Switzerland) was also used to cover the strip to avoid dehydration of the gel. The whole assembly was incubated at $20^{\circ} \mathrm{C}$ overnight.

First-dimension (isoelectric focusing). To perform isoelectric focusing, flat-bed isoelectric focusing equipment (Amersham Pharmacia Biotech, Amersham, UK) was used. The chiller was set at $20^{\circ} \mathrm{C}$ and the IPG strips were removed from the rehydration tray and aligned $2 \mathrm{~mm}$ apart on the flat bed chamber with the gel side facing upward. Silicon oil (Fluka) was pre-coated on the cooling plate of the focusing chamber to avoid the thermal fluctuations beyond $20^{\circ} \mathrm{C}$. The time and voltage specifications for the steps involved in the focusing operation are listed in Table II.

Second dimension (SDS-PAGE). The freeze-focused strips were placed at room temperature until normalized. Equilibration buffers (1 and 2) were prepared and the strip was carefully transferred with the gel side facing upward to the rehydration tray. Equilibration buffer (10 ml; stock) was added for removal of the residual buffer reagents that were used in the first dimension followed by equilibration steps. A $0.5 \%$ molten agarose gel was evenly layered over the horizontal surface of a $12 \%$ polyacrylamide gel, standard protein marker (cat no. SM0661; PageRular; Fermantas, Waltham, MA, USA) was loaded and the gel was run at a constant voltage of $60 \mathrm{~V}$ until the sample remained in the agarose gel. The voltage was then increased to $120 \mathrm{~V}$ as the sample migrated to the resolving gel. Protein fixation, staining and destaining of the gel was performed, as described previously, and the gel was scanned using a gel documentation system (GeneSnap; Syngene). Following comparison of the patient and control gel images, the differentially expressed protein spots were observed, marked and labeled.

\section{In-gel digestion.}

The in-gel digestion procedure included the following steps:

Washing and destaining of the protein spot. Following 2DE and image analysis, the gel was washed with fresh deionized water. The marked, differentially expressed, protein spot was excised by comparing the respective gel images using a sterilized, methanol washed, metal blade and transferred to a clean and sterile microfuge tube containing deionized water. Following incubation at room temperature for $15 \mathrm{~min}$, the protein gel spot was washed with a mixture of $100 \mu \mathrm{l}$ acetonitrile (ACN; Sigma-Aldrich) and double distilled water in equal ratio and was incubated at room temperature for $15 \mathrm{~min}$. Following removal of the mixture, $100 \mu \mathrm{l} \mathrm{ACN}$ was added in each tube and incubated until the gel spot was white and sticky. Subsequently, following removal of the ACN, $100 \mu 1$ of $100 \mathrm{mM}$ ammonium bicarbonate (; Ambic), which was prepared by dissolving $0.079 \mathrm{~g}$ ammonium bicarbonate in $10 \mathrm{ml}$ autoclaved deionized water ( $\mathrm{pH} 8.0$ ), was added followed by $5 \mathrm{~min}$ incubation at room temperature. An equal quantity of ACN was added to the tube in a 1:1 solution and was incubated again for $15 \mathrm{~min}$. The solution was removed and the gel spot was desiccated in a freeze dryer (Alpha1-4, Loc-Im; Martin Christ, Osterode am Harz, Germany).

Reduction and alkylation. A solution of $100 \mu \mathrm{l}$ of $10 \mathrm{mM}$ DTT (prepared by mixing $50 \mu \mathrm{l}$ of $200 \mathrm{mM}$ DTT and $950 \mu 1$ of $100 \mathrm{mM}$ Ambic) was added to the dried protein spot from the gel for reduction of the disulphide bonds in the protein, followed by incubation at $56^{\circ} \mathrm{C}$ for $45 \mathrm{~min}$. This was followed immediately by the addition of $100 \mu 155 \mathrm{mM}$ iodoacetamide (IAA) containing $0.101 \mathrm{~g}$ IAA in $10 \mathrm{ml} 100 \mathrm{mM}$ Ambic, following removal of the reducing solution and incubation in the dark for $30 \mathrm{~min}$. The solution was removed again and the spot was washed with $100 \mathrm{mM}$ Ambic followed by a 5-min incubation. An equal quantity of ACN was added to produce a 1:1 solution, which was further incubated for $15 \mathrm{~min}$. The protein gel spot was fully dried, as previously, in a freeze dryer. 


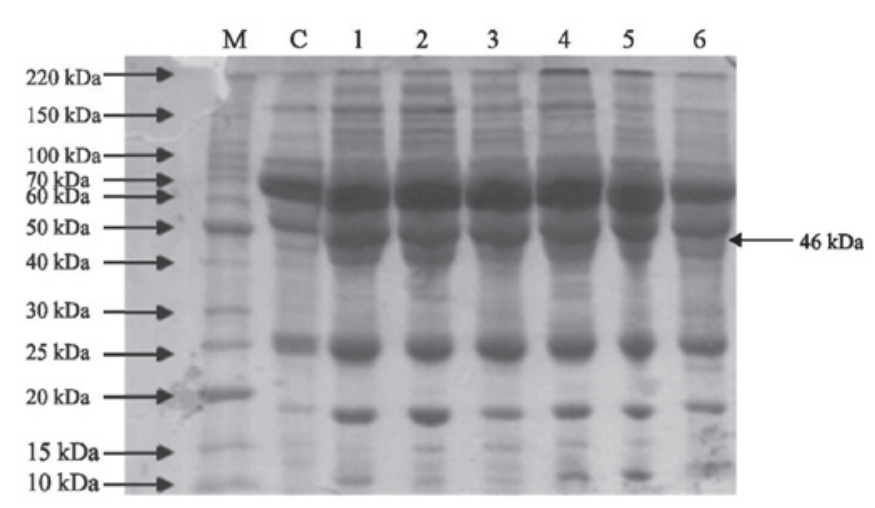

Figure 1. One-dimensional sodium dodecyl sulphate polyacrylamide gel electrophoresis $(12 \%)$ resolution of the serum proteins expressed in adenocarcinoma samples and the healthy control (lane $\mathrm{M}$, unstained protein ladder; Invitrogen Life Technologies). Lane C, control serum; lanes 1-6, adenocarcinoma samples.

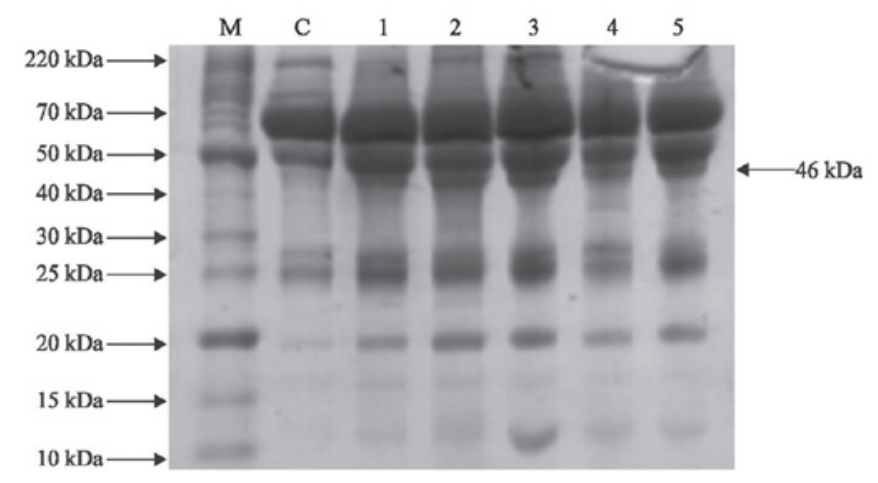

Figure 2. One-dimensional sodium dodecyl sulphate polyacrylamide gel electrophoresis $(12 \%)$ resolution of the proteins expressed in squamous cell carcinoma samples and the healthy control (lane $\mathrm{M}$, unstained protein ladder; Invitrogen Life Technologies). Lane C, control serum; lanes 1-5, squamous cell samples. Serum proteins $(10 \mu \mathrm{g})$ from the patients and control individuals were loaded onto the gel and the differential protein pattern was observed following colloidal coomassie G-250 staining.

Peptide digestion. A total of 400 ng of trypsin, reconstituted in $50 \mathrm{mM}$ Ambic, was added to each gel spot and incubated on ice for $45 \mathrm{~min}$. The solution was then discarded and $50 \mathrm{mM}$ Ambic was added, ensuring that the gel spot was entirely soaked, followed by incubation at $37^{\circ} \mathrm{C}$ overnight.

Peptide extraction. The peptide extract was acidified with $10 \%$ trifluoroacetic acid (TFA) to $\sim \mathrm{pH} 3$ and the peptide extract supernatant was removed and stored in a clean microfuge tube. The residual gel slice was covered again with TFA and ACN (0.1:60) and placed in an ultrasonic water bath (Ultrasonic LC30/H; Elma, Singen, Germany) for $30 \mathrm{~min}$ at $20^{\circ} \mathrm{C}$ for further peptide extraction. The final peptide extract, which was pooled from the supernatants, was dried in a freeze dryer and the liquid volume was reduced up to $10 \mu 1$ followed by storage at $-20^{\circ} \mathrm{C}$ until MALDI/TOF/TOF analysis.

Peptide mass fingerprinting (MALDI-TOF/TOF) and database analysis. The mass spectrometric procedure was performed using an $\alpha$-hydroxycinnamic acid matrix (Bruker Daltonics, Bremen, Germany) according to the manufacturer's instructions and the resulting peaks list was subjected to a Mascot search analysis (www.matrixscience.com) following baseline adjustment and screening of noises using flex analysis to identify the proteins. The Mascot database search parameters were set as follows: carbamidomethyl modification of cysteine, possible oxidation of methionine up to one missed cleavage and trypsin (cat no. V5111; Promega Corporation, Madison, WI, USA) for proteolytic cleavage. The sequence coverage level, matching peptide numbers and Mascot score parameters were used to confirm the identification. The SwissProt database (http://www.uniprot.org/) was used for protein identification.

Immunological investigation of targeted proteins. In order to establish a set of lung cancer protein biomarkers for screening and therapeutic applications, by correlating the expression level of a particular protein in all the patient and control samples, the differentially expressed proteins were targeted for further evaluation and estimation. Western blot analysis was performed to confirm the presence of the targeted protein in the serum samples.

Western blot analysis. Western blot analysis was performed according to the method described by Towbin et al (17). A total of $10 \mu \mathrm{g}$ serum proteins from all the serum samples were resolved on a $15 \%$ SDS-gel, which was run by the method described by Laemmli (16), transferred onto a nitrocellulose blotting membrane sheet of $8.5 \times 7.5 \mathrm{~cm}$ dimension and $0.22 \mu \mathrm{m}$ pore size (Cat no. 786-018NC; G-Biosciences, St. Louis, MO, USA) and the protein transfer was continued for $1.5 \mathrm{~h}$ at constant voltage $(18 \mathrm{~V})$ in a semi dry transfer cell assembly (Trans-Blot Sd; Bio-Rad, Hercules, CA, USA). The primary anti-haptoglobin $\beta$-chain antibody $[1: 10,000 ;(2 \mathrm{~F} 4)$ LF-MA0158; Abfrontier, Seoul, Korea] was added to the blot followed by incubation at $4^{\circ} \mathrm{C}$ overnight for maximum binding of the antibody to its antigenic site. Subsequently, the blot was washed three times with Tris-buffered saline containing $0.01 \%$ Tween-20, and goat anti-mouse immunoglobulin (Ig) G, alkaline phosphatase (AP)-conjugated secondary antibody (cat no. 786-R43; G-Biosciences) was added followed by incubation at room temperature for $2 \mathrm{~h}$ followed by three washings with the same wash buffer. The blot was finally developed using AP-substrate buffer solution.

\section{Results and Discussion}

Lung cancer represents one of the major causes of cancer-associated mortality worldwide (18). It is one of the most commonly occurring and the most life-threatening types of neoplasia in numerous areas of the world and is responsible for $25 \%$ of cancer-related mortality (19). Biomarkers are assessment tools for a particular biological condition. Cancer biomarkers may assist in patient diagnosis and disease handling by stage characterization and evaluation of therapeutic feedback (20).

SDS-PAGE of patient and control serum. All serum samples were subjected to SDS-PAGE following the estimation of total protein content using the above-mentioned procedure. Total serum protein $(10 \mu \mathrm{g})$ from each patient and control was resolved on a $12 \%$ SDS-gel using Bio-Rad mini gel assembly followed by protein fixation, staining and destaining steps, as previously described. One-dimensional 
Table III. Mass spectrometric analysis parameters for the protein profiling of the in-gel-digested peptides.

\begin{tabular}{|c|c|c|c|c|c|c|c|c|}
\hline $\begin{array}{l}\text { Laser beam } \\
\text { wavelength }(\mathrm{nm})\end{array}$ & $\begin{array}{l}\text { Digitizer } \\
(\mathrm{GHz})\end{array}$ & $\begin{array}{l}\text { Mode of } \\
\text { analysis }\end{array}$ & $\begin{array}{l}\text { Ion acceleration } \\
(\mathrm{kv})\end{array}$ & $\begin{array}{l}\text { Lens potential } \\
\qquad(\mathrm{kv})\end{array}$ & $\begin{array}{c}\text { Laser } \\
\text { frequency }(\mathrm{Hz})\end{array}$ & $\begin{array}{c}\text { Intensity } \\
(\%)\end{array}$ & $\begin{array}{l}\text { Detector } \\
\text { gain }\end{array}$ & $\begin{array}{c}\text { Sample } \\
\text { rate }(\mathrm{GS} / \mathrm{s})\end{array}$ \\
\hline 337 & 2 & Linear positive & 25 & 6 & 100 & $60-70$ & 7.5 & 0.5 \\
\hline
\end{tabular}

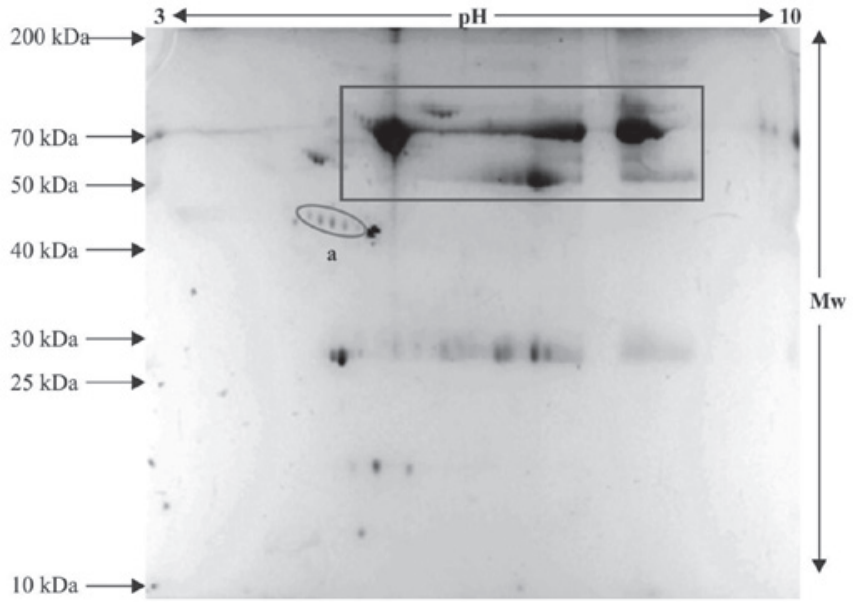

Figure 3. Two-dimensional serum protein profiling of the healthy control. The protein marker (Page Rular; Fermentas; cat.no SM0661) is shown on the left. The protein spots 'a', indicated within the oval, were selected as the standard for comparison of the relative expression in the patients. Abundantly occurring proteins, including albumin and immunoglobulins are indicated within rectangles.

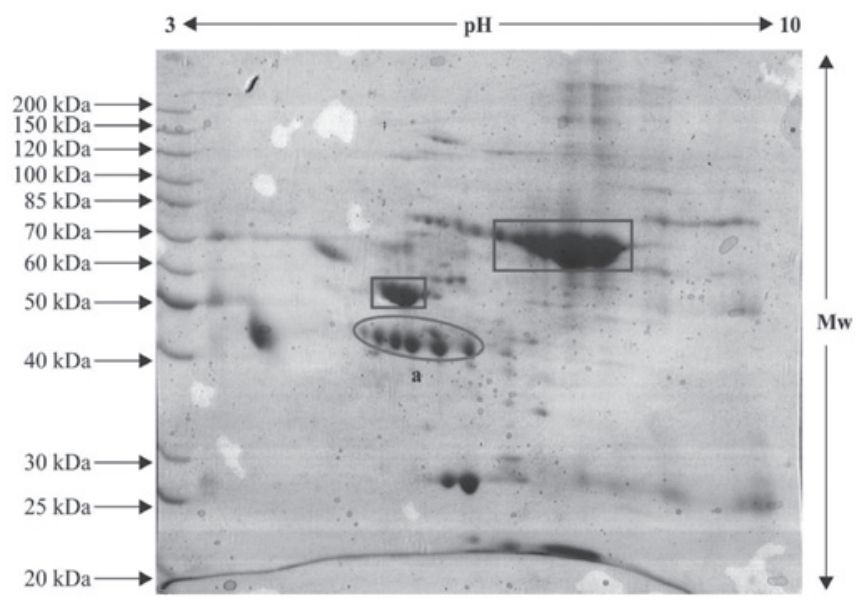

Figure 4. Two-dimensional serum protein profiling of the squamous cell carcinoma sample. The protein marker (Page Rular; Fermentas; cat.no SM0661) of $10-200 \mathrm{kDa}$ is indicated on the left. The overexpressed protein spots 'a' are indicated within the oval along and the abundantly occurring proteins, including albumin and immunoglobulins are indicated within the rectangles.

gel electrophoresis demonstrated a compact protein banding pattern in the control and lung cancer serum samples, as shown in Figs. 1 and 2. Differential expression was observed at various positions in the adenocarcinoma and squamous cell carcinoma patient samples. A protein with a molecular weight of $\sim 46 \mathrm{kDa}$ was overexpressed in the adenocarcinoma and squamous cell carcinoma patient samples compared with the control (Figs. 3-5).

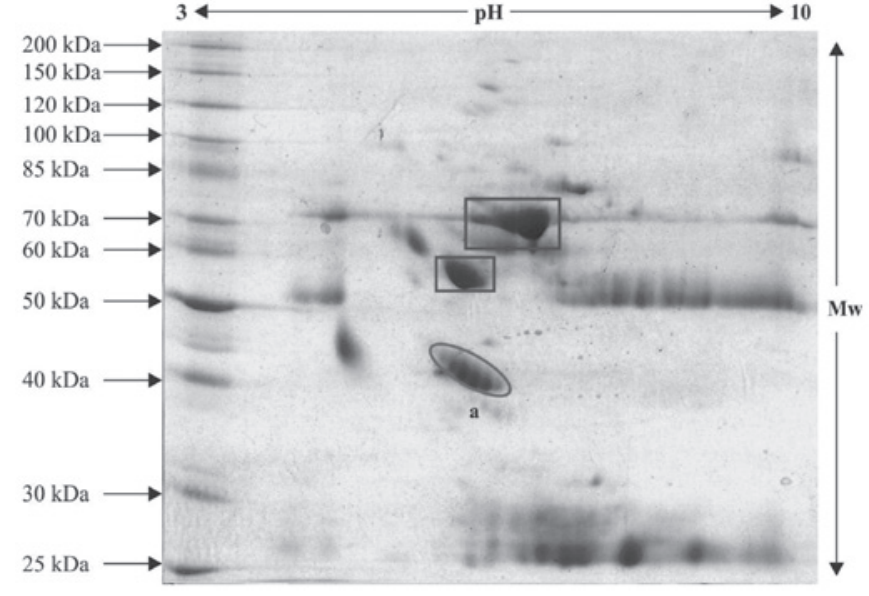

Figure 5. Two-dimensional serum protein profiling of the lung adenocarcinoma sample. The protein marker (Page Rular; Fermentas; cat.no SM0661) of $10-200 \mathrm{kDa}$ is indicated on the left. The overexpressed protein spots 'a' are indicated within the oval. The abundantly occurring proteins, including albumin and immunoglobulins are marked within the rectangles.

$2 D E$. The serum proteins from the patient and control samples were resolved on IPG strips and subsequent steps were performed, as described above. The control and patient sample gels exhibiting variable pattern and differentially expressed protein spots were subjected to tryptic digestion and further protein profiling, as the spots appeared with defined boundaries and were expressed in an unusual pattern. These were selected for mass spectrometric analysis. The protein spots, which were relatively differentially expressed in the patient samples compared with the controls are indicated within ovals in the 2-D gels (Figs. 3-5) and the serum proteins, which were observed in abundance, are indicated within rectangle boxes. A relatively high expression level of the $\sim 42-46 \mathrm{kDa}$ protein was observed (spot 'a' in Figs. 4 and 5), compared with spot 'a' in the control gel (Fig. 3). This spot was selected for in-gel digestion and mass spectrometric investigations.

MALDI-TOF/TOF or peptide mass finger printing analysis of the protein spots. Following in-gel digestion of the differentially expressed protein spots, peptide mass fingerprinting was performed to identify the protein, with a protein exhibiting high confidence (Mascot score $>60$ and sequence coverage $\geq 20 \%$ ) considered to be valid. The mass spectrometric analysis parameters are summarized in Table III, the Mascot specifications are shown in Table IV and the mass spectrum, score histrogram and peptide profile of the identified protein are shown in Fig. 6. The Mascot analysis of the identified peptides recognized the protein as human haptoglobin (experimental mass $45.861 \mathrm{kDa}$ ), which has optimal confidence parameters of a Mascot score of 87 , sequence coverage of $23 \%$, isoelectric 
point of 6.13 and accession no. P00738. These values are based on mass spectrometry and Mascot analysis. The observed isoelectric point of the protein (5.5-6.2) was comparable to the experimental one (6.13). The discrepancy from original value was attributed to post-translational modifications.

Human haptoglobin. Following excision, in-gel digestion, MALDI/TOF/TOF analysis and database examination, the marked protein spot 'a' was identified as haptoglobin. The protein had a molecular weight of $45.861 \mathrm{kDa}$, isoelectric point of 6.13, Mascot score of 87 and had 23\% sequence coverage. The spectral view and Mascot score histogram are shown in Fig. 6A and B, respectively, while the matched sequence of peptides are shown in Fig. 6C.

Immunological validation of haptoglobin by western blot analysis. To support and justify the results of the MALDI/TOF/TOF analysis, western blot analysis was performed for haptoglobin using the procedure described above. This immunological practice offers economical and valuable implementation for the screening and detection of a particular antigen in any biological sample. The haptoglobin protein demonstrated significant upregulation in the squamous cell carcinoma and adenocarcinoma groups, with relatively high expression in squamous cell carcinoma (Fig. 7A and B). The results revealed a high degree of immunoreactivity of this acute phase protein by detecting dense bands at $\sim 46 \mathrm{kDa}$, which confirmed high expression in the squamous cell and adenocarcinoma groups compared with the control. Protein bands were also observed at several other positions, including 33, 25 and $50 \mathrm{kDa}$. This may have been due to the presence of various isoforms of the haptoglobin protein exhibiting affinity to the antibody. It is a common occurrence that antibodies raised against the $\beta$-chain of haptoglobin also attach to pre-pro-haptoglobin and pro-haptoglobin, as these proteins consist of the complete amino acid sequence of the $\beta$-chain of haptoglobin (21). The $25 \mathrm{kDa}$ protein band (Fig. 7A) corresponds to the $\alpha$-isoform (22), whilst the $33 \mathrm{kDa}$ protein (Fig. 7B) corresponds to the unglycosylated $\beta$-chain, as reported by Oda et al (23). The $50 \mathrm{kDa}$ protein band appears to be either an albumin-degraded fragment or pro-haptoglobin, as described in a previous study (21). However, Kang et al (7) recognized the haptoglobin protein as 9,19 and $45 \mathrm{kDa}$ protein products, differing from their estimated masses. This study suggested that $\beta$-chain of the haptoglobin protein may be $\mathrm{N}$-glycosylated and, therefore, identified at the higher molecular mass of $45 \mathrm{kDa}$, which was confirmed by Peptide:N-glycosidase F treatment.

In the present study, of all the proteins expressed, the highest signal was obtained at $46 \mathrm{kDa}$ revealing that this isoform of haptoglobin exhibited maximum expression compared with the other isoforms (Fig. 7A and B). The normal molecular mass of the $\beta$-subunit of haptoglobin is $38 \mathrm{kDa}$ (13), however the haptaglobin molecular mass of $46 \mathrm{kDa}$ appeared to be due to glycosylation. Modifications to the $\beta$-subunit of haptoglobin by glycosylation have been previously reported (24). Therefore, the glycosylated haptoglobin $\beta$-chain may serve as a sensitive predictor of lung cancer compared to non-glycosylated forms and the high expression of glycosylated $\beta$-haptoglobin in squamous cell carcinoma compared with adenocarcinoma may 
A
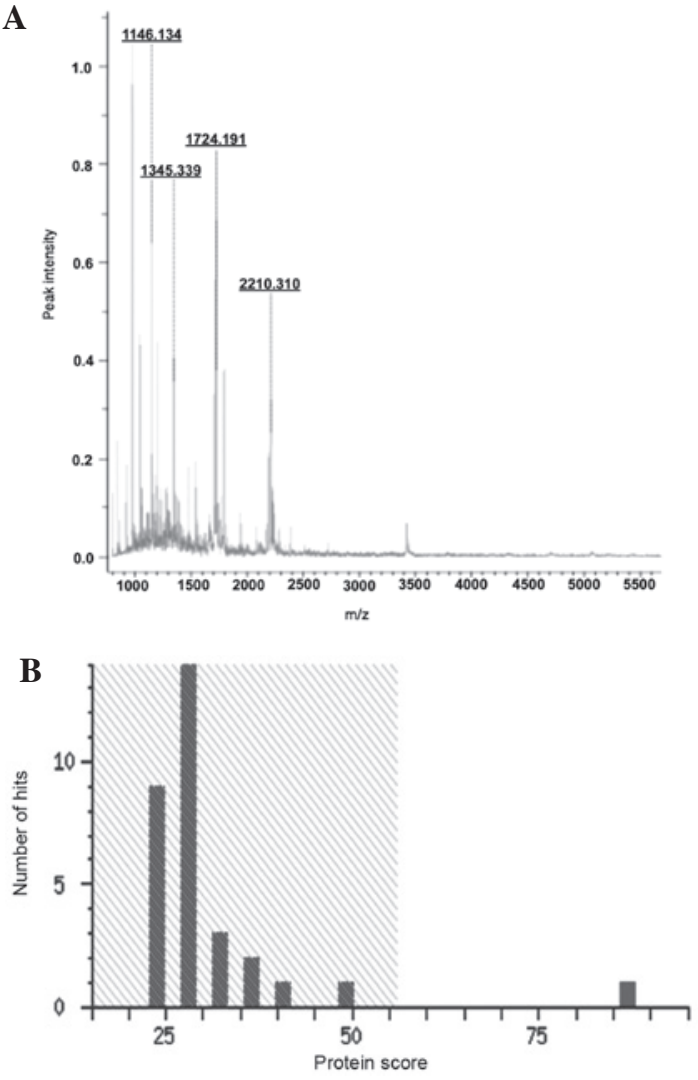

C

$\begin{array}{llllll}1 & \text { MSALGAVIAL } & \text { LLWGQLFAVD } & \text { SGNDVTDIAD } & \text { DGCPKPPEIA } & \text { HGYVEHSVRY } \\ 51 & \text { QCKNYYKLRT } & \text { EGDGVYTLND } & \text { KKQWINKAVG } & \text { DKLPECEADD } & \text { GCPKPPEIAH } \\ 101 & \text { GYVEHSVRYQ } & \text { CKNYYKLRTE } & \text { GDGVYTLNNE } & \text { KQWINKAVGD } & \text { KLPECEAVCG } \\ 151 & \text { KPKNPANPVQ } & \text { RILGGHLDAK } & \text { GSFPWQAKMV } & \text { SHHNLTTGAT } & \text { LINEQWLLTT } \\ 201 & \text { AKNLFLNHSE } & \text { NATAKDIAPT } & \text { LTLYVGKKQL } & \text { VEIEKVVLHP } & \text { NYSQVDIGLI } \\ 251 & \text { KLKQKVSVNE } & \text { RVMPICLPSK } & \text { DYAEVGRVGY } & \text { VSGWGRNANF } & \text { FTDHLKYVM } \\ 301 & \text { LPVADQDQCI } & \text { RHYEGSTVPE } & \text { KKTPKSPVGV } & \text { QPILNEHTFC } & \text { AGMSKYQEDT } \\ 351 & \text { CYGDAGSAFA } & \text { VHDLEEDTWY } & \text { ATGILSFDKS } & \text { CAVAEYGVYV } & \text { KVTSIQDWVQ } \\ 401 & \text { KTIAEN } & & & & \end{array}$

Figure 6. (A) Mass spectrometric chromatogram of haptoglobin. (B) Score histogram of haptoglobin. (C) A symbolic representation of the identified peptides of haptoglobin among the theoretical and experimental data. The matched peptides are marked in bold with the unmatched peptides remaining.

A

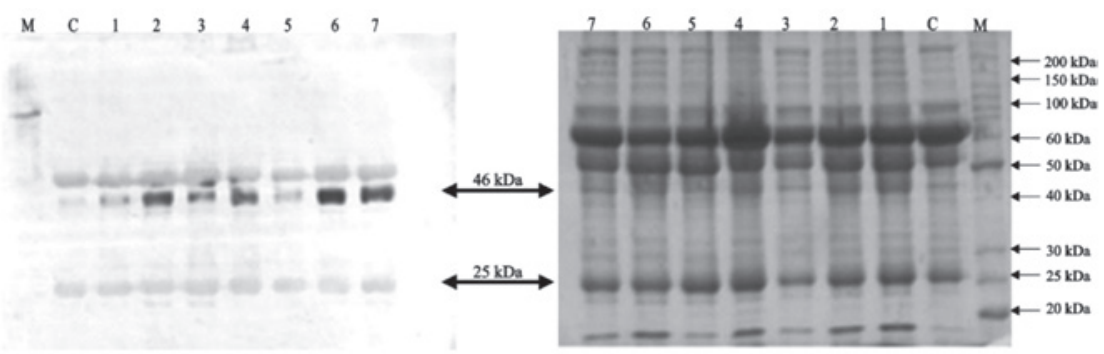

B

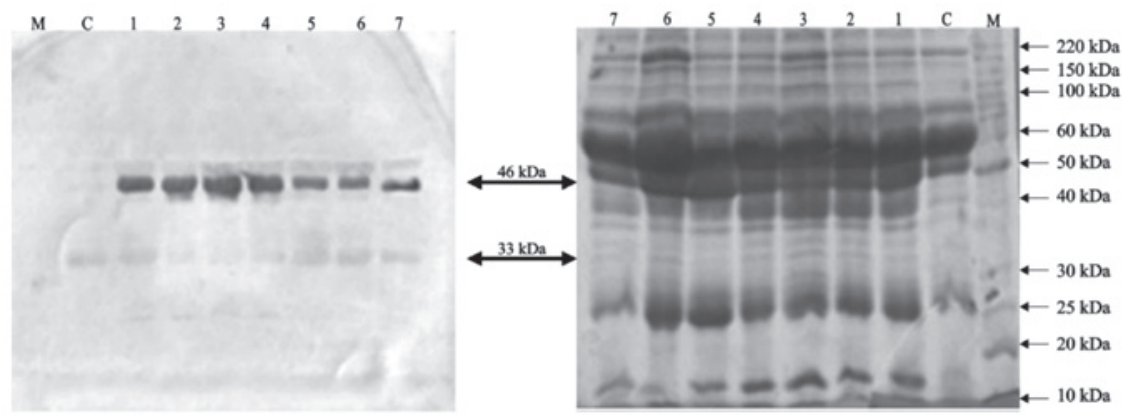

Figure 7. Immunodot blot validation of the lung cancer serum sample against the haptoglobin protein. (A) Lane M, protein marker (Invitrogen Life Technologies); Lane C, control serum; lanes 1-7, adenocarcinoma samples. (B) Lane M, protein marker; Lane C, control serum; lanes 1-7, squamous cell carcinoma samples. 
further assist in differentiating between the histopathalogical types of lung carcinoma.

The results of the present study assist in the establishment of a screening methodology to evaluate and monitor the expression of a particular disease biomarker in serum and to access the treatment response of disease in patients. On the basis of lung cancer serum protein profiling coupled with immunological confirmation, the haptoglobin $\beta$-chain may offer a candidate lung cancer protein biomarker for novel therapeutic targets to improve the survival rates in patients with lung cancer. The role of smoking was found to be critical during the course of the present study, therefore, positive planning to improve outcomes is required and the only technique to eradicate this alarming public health issue is intersectoral collaboration. This biomarker protein may assist in investigating in depth metabolic pathways and to establish a set of therapeutic agents leading to early detection of disease. In addition, conveying and communicating awareness to smoking hazards and its life-threatening consequences is required worldwide in order to decrease mortality rates and to promote the eradication of lung cancer resulting in improved survival rates.

By following several important preventive measures, the incidence of lung cancer can be reduced. These include prohibiting smoking and passive smoking, which increases the risk of developing lung cancer more than smoking itself and wearing masks while on roads, as several lung cancer patients involved in the present study were exposed to air pollution or occupational toxicity. Menthol cigarettes facilitate the deep penetration of toxic smoke compounds and have been found to be more harmful and, in females, the trend can also be minimized by excluding the use of talc-based cosmetics, which causes serious injury to lungs.

\section{References}

1. Chen G, Gharib TG, Wang H, Huang CC, Kuick R, Thomas DG, Shedden KA, Misek DE, Taylor JMG, Giordano TJ, Kardia SLR, Iannettoni MD, Yee J, Hogg PJ, Orringer MB, Hanash SM and Beer DG: Protein profiles associated with survival in lung adenocarcinoma. Proc Natl Acad Sci USA 100: 13537-13542, 2003

2. Brambilla E, Travis WD, Colby TV, Corrin B and Shimosato Y: The new World Health Organization classification of lung tumours. Eur Respir J 18: 1059-1068, 2001.

3. Dalton WS and Friend SH: Cancer biomarkers - an invitation to the table. Science 312: 1165-1168, 2006.

4. Fung ET, Wright GL Jr and Dalmasso EA: Proteomic strategies for biomarker identification: progress and challenges. Curr Opin Mol Ther 2: 643-650, 2000.

5. Sung HJ and Cho JY: Biomarkers for the lung cancer diagnosis and their advances in proteomics. BMB Rep 41: 615-625, 2008.
6. Druker BJ: Imatinibmesylate in the treatment of chronic myeloid leukaemia. Expert Opin Pharmaco ther 4: 963-971, 2003.

7. Kang SM, Sung HJ, Ahn JM, Park JY, Lee SY, Park CS and Cho JY: The Haptoglobin $\beta$ chain as a supportive biomarker for human lung Cancer. J Mol Bio Syst 7: 1167-1175, 2011.

8. Maciel CM, Junqueira M, Paschoal ME, Kawamura MT, Duarte RL, CarvalhoMda G and Domont GB: Differential proteomic serum pattern of low molecular weight proteins expressed by adenocarcinoma lung cancer patients. J Exp Ther Oncl 5: 31-38, 2005.

9. Gruys E, Toussaint MJM, Niewold TA and Koopmans SJ: Acute phase reaction and acute phase proteins. J Zhejiang Univ Sci B 6: 1045-1056, 2005.

10. Kasprzyk M, Dyszkiewicz W, Zwarun D, Lesniewska K and Wiktorowicz K: The assessment of acute phase proteins as prognostic factors in patients surgically treated for non-small cell lung cancer. Pneumonol Alergol Pol 76: 321-326, 2008 (In Polish).

11. Andersen MN, Mouritzen CV and Gabrielli ER: Mechanisms of plasma hemoglobin clearance after acute hemolysis in dogs: serum haptoglobin levels and selective deposition in liver and kidney. Ann Surg 164: 905-912, 1966.

12. Kurosky A, Barnett DR, Lee TH, Touchstone B, Hay RE, Arnott MS, Bowman BH and Fitch WM: Covalent structure of human haptoglobin: a serine protease homolog. Proc Natl Acad Sci USA 77: 3388-3392, 1980.

13. Patzelt D, Geserick G and Schroder H: The genetic haptoglobin polymorphism: relevance of paternity assessment. Electrophoresis 9: 393-397, 1988.

14. Bradford MM: A rapid and sensitive method for the quantitation of microgram quantities of protein utilizing the principle of protein-dye binding. Anal Biochem 72: 248-254, 1976.

15. Judd RC: Purification of outer membrane proteins of the gram-negative bacterium Neisseria gonorrhoeae. Anal Biochem 173: 307-316, 1988.

16. Laemmli UK: Cleavage of structural proteins during the assembly of the head of bacteriophage T4. Nature 227: 680-685, 1970.

17. Towbin HK, Staehelin T and Gordon J: Elerophoretic transfer of protein from polyacrylamide gels to nitrocellulose membrane. Proc Natl Acad Sci USA 76: 4350-4359, 1979.

18. Parkin DM, Bray F, Ferlay J and Pisani P: Global cancer statistics. J Clin 55: 74-108, 2002, 2005.

19. Jemal A, Siegel R, Ward E, Murray T, Xu J, Smigal C and Thun MJ: Cancer statistics. J Clin 56: 106-130, 2006.

20. Ludwig JA and Weinstein JN: Biomarkers in cancer staging, prognosis and treatment selection. Nat Rev Cancer 5: 845-856, 2005.

21. Hanley JM, Haugen TH and Heath EC: Studies on the biosynthesis of rabbit Haptoglobin. J Biol Chem 258: 7858-7869, 1983.

22. Langlois MR and Delanghe JR: Biological and clinical significance of haptoglobin polymorphism in humans. Clin Chem 42: $1589-1600,1996$

23. Oda K, Miki K, Hirose S, Takami N, Misumi Y and Ikehara Y: Immunoblotting analysis of plasma protein processing in the secretory pathway of rat liver: identification of proteolytic conversion sites of complement pro-C 3 and prohaptoglobin. J Biochem 100: 1669-1675, 1986.

24. Hoagland L, Campa M, Gottlin E, Herndon J and Patz E: Haptoglobin and post-translational glycan-modified derivatives as serum biomarkers for the diagnosis of non-small cell lung cancer. 110: 2260-2268, 2007. 